\title{
Europe holds fire on spy satellite plan ...
}

Paris. Europe's joint security organization, the ten-nation Western European Union (WEU), has agreed to turn its experimental satellite ground station in Torrejon, near Madrid in Spain, into a permanent facility.

But it has postponed any decision on how to proceed with related plans to develop a European military satellite system - a decision which will depend on how Europo eventually responds to offers of coopcration from the United States.

At present, the main activity of the Torrejón centre is the processing of satellite images from SPOT and other commercial suppliers, to verify arms agreements, and to monitor both security crises (for example in Bosnia) and environmental changes.

WEU is currently considering building its own satellites for telecommunications, highresolution Earth observation, and cavesdropping. But its member states continuc to balk at the costs of such a programme, estimated at $\$ 840$ million a year for 25 years.

Lanfranco Emiliani, director of Earth observation and environmental programmes at the European Space Agency (ESA), has suggested that one way to cut the costs of European military programmes would be to exploit synergy with ESA programmes.

\section{... as CIA shows off its early efforts}

Washington. Early satellite photographs of China and the Soviet Union taken by satellites launched under the oncesecret Corona programme have been released as part of an effort by the US Central Intelligence Agency to explain its mission to the public.

The images include that of the Chinese nuclear test site at Lop Nur (far right) taken on 20 0ctober 1964, four days after China conducted its first

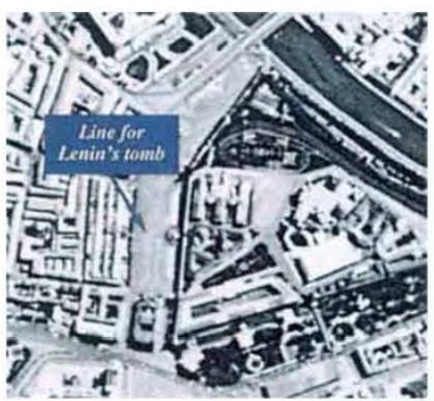
nuclear test. Another (above), taken above Moscow on 28 May 1970 with a resolution of about 6 feet, shows the queue for Lenin's tomb.

The Corona programme conducted Its first successful mission in August 1960 , three months after a Sovlet misslle had brought down the U-2 spy plane on which the United States had prevlously been dependent. But the first mission alone obtained more data than all of the U-2's flights had done, and for the next decade, the CIA was deluged with information.

Another option would be for WEU to obtain data from Helios-l, a military observation satellite built by France, Italy and Spain which will be launched this year, as well as other military satellites planned by European nations.

WEU has, indeed, already signed a memorandum of understanding with France to obtain some classified images from Hclios-1. But officials from the Helios-l programme are reported to be very reluctant to share data with countries which have not contributed to the costs of building the satellite.

Bhupendra Jasani, of the Department of War Studies at King's College in I ondon, argues that WEU will wait to find out what data it will be able to obtain from Helios-1 before taking a decision on whether to build its own system.

Negotiations are further complicated by the high stakes involved in devcloping military satellite systems. At the political level, the major space powers - such as the United States, Russia and France - seem determined to maintain their technological lead, and to prevent the proliferation of high-resolution ( 1 metre) images, just as nuclear powers are keen to prevent non-nuclear states from building nuclear weapons.
Unveiling some of it at a symposium at George Washington University, John Deutch, professor of chemlstry at the Massachusetts Institute of Technology and newly-appointed director of the CIA, praised the links between scientists, industry and government that enabled Corona to succeed.

This appears partly to explain the relative enthusiasm of the United States, France and the United Kingdom to cooperate on an international military telecommunications satellite programme, Immilsat, which would also take advantage of the fact that all three countries need to replace their existing military satellites around 2005 .

But thesc countries are also determined both to protect their domestic satellite industries and to boost their international competitiveness. Germany, for cxample, is expected to invest in the French-led Helios2 programme; but it has repeatedly postponed a firm commitment in what is widely being interpreted as a bid to negotiate better industrial returns from the project.

The political and industrial stakes are perhaps best illustrated by the current stance of the United States. In March, Gil Klinger, the US Defense Department's acting deputy undersecretary for space acquisition and technology, offered to cooperate with Europe on an international military satellite system, and promised that the United States would not impose undue control over any jointly developed systems.

In particular, Klinger said that President Bill Clinton supports transatlantic conperation on a Space-Based Infrared System, already scheduled for launch in 2002 as a replacement for the US Defense Support Program's missile-detecting satellite system.

But Klinger's offer is being vicwed with scepticism by those in Europe who point out that the United States faces a dilemma. If it prohibits its aerospace companies from selling high-resolution satellites to other countries, it will lose business; but such countries risk cventually finding alternative suppliers, which would result in the proliferation of high-resolution images.

The United States now seems to have decided that if it cannot prevent commercial operators putting classified images on the market, it would prefer [if such images] were being sold by US companies that the Pentagon can control during a security crisis. "The US political manoeuvring is clear," argues Stephane Chenard from the Paris-based space consultancy, Euroconsult.

Indeed, some Europcans believe that a Europe-only satellite system, known as Eumilsatcom, would be preferable, as it would both defend the local industries and make Europe less dependent on the United States for satellite data.

Barry Blaydes, the director of the Torre"This team had enormous technical obstacles to overcome and no time for lengthy preliminary studies," he said.

The release of the Corona data has been long sought by vice-president Al Gore, who believes that it will be of great value to environmental scientists. jón centre, says the question of whether WEU builds its own satellite system will "take time to resolve." He points out, howcver, that the centre can, meanwhile, continuc to opcrate with procured images, although adding that the acquisition of highresolution Helios data will be "an important stcp" in its futurc.

Declan Butler 